V. 12 N. 2

MAI-AGO 2016

ISSN 2317-6172

Recebido: 06.02.2014

Aprovado: 18.04.2016

Dol: http://dx.doi.org/10.1590/2317-6172201620

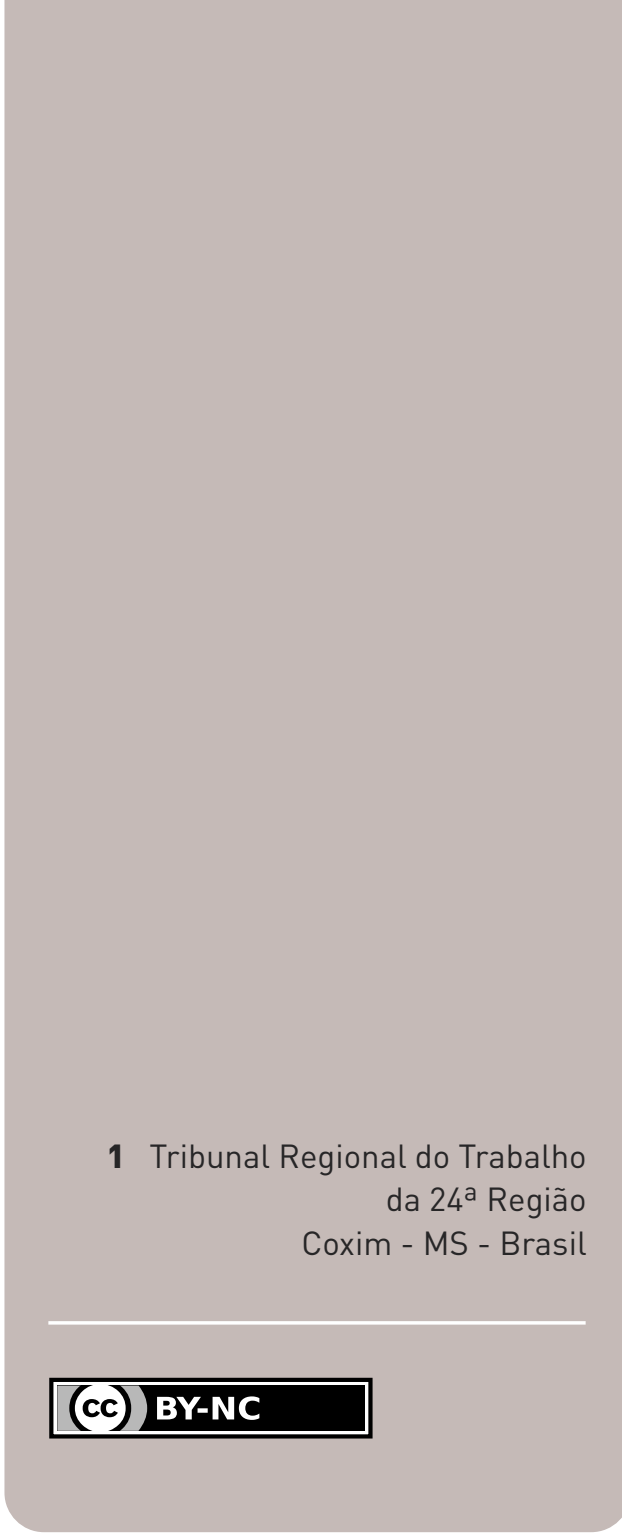

\section{Assédio sexual no trabalho e discriminação de gênero: duas faces da mesma moeda?}

SEXUAL HARASSMENT AND GENDER DISCRIMINATION: TWO SIDES OF THE SAME COIN?

\author{
Flávio da Costa Higa
}

\section{Resumo}

0 artigo tem por objeto de investigação a igualdade de gênero nas relações de trabalho. A partir da contextualização histórica da divisão sexista de atribuições sociais, busca demonstrar as dificuldades de inserção da mulher no mercado de trabalho, diante das estruturas patriarcais de poder. Pretende, com isso, avaliar, de forma mais específica, a relação existente entre assédio sexual e discriminação de gênero, fazendo aproximações críticas entre os dois fenômenos, mediante análise de textos legais e de decisões judiciais pertinentes ao tema. Tem como argumento central a validade teórica da premissa de o assédio sexual ser encarado como possível manifestação discriminatória - notadamente quando implique reprodução de estereótipos e normas de gênero -, porém sem excluir a possibilidade de ser tratado como violação da dignidade da pessoa humana e do direito ao meio ambiente de trabalho saudável e equilibrado. Propõe, finalmente, uma abordagem global como meio mais eficaz de enfrentamento da questão.

\section{Palavras-chave}

Assédio sexual; gênero; mulher; discriminação; trabalho.

\section{Abstract}

The purpose of the article is to investigate gender equality in labor relations. From the historical context of the sexist division of social attributes, it seeks to show the difficulties of inserting women into the labor market considering the patriarchal power structure. Thereby the article tries, on a more specific basis, to assess the relationship between sexual harassment and gender discrimination, with a critical comparison of the two phenomena, by analyzing pertinent legal texts and court decisions. The central argument is the theoretical validity of the premise that sexual harassment is regarded as a possible expression of discrimination - especially when it implies the reproduction of gender stereotypes and norms - but without excluding the possibility of treating it as a violation of human dignity and the right to enjoy a healthy and balanced working environment. Finally, it proposes a global approach as a more effective mean of dealing with the issue.

\section{Keywords}

Sexual harassment; gender; woman; discrimination; labor. 
Na boca do homem o epíteto "fêmea" soa como um insulto; no entanto, ele não se envergonha de sua animalidade, sente-se, ao contrário, orgulhoso se dele dizem: “É um macho!” O termo "fêmea" é pejorativo, não porque enraíze a mulher na natureza, mas porque a confina no seu sexo.

(BEAUVOIR, 1970, p. 25)

\section{INTRODUÇÃO}

A expressão "igualdade de gênero" ostenta uma aparente contradição ontológica, porquanto a ciência encarregou-se de demonstrar que os seres humanos - independentemente do sexo são diferentes entre si, o que os torna, em certa medida, únicos. Essa peculiaridade faz da "virtude soberana" da igualdade um conceito bastante volátil e controverso, que não possibilita às pessoas que o exaltam ou depreciam saberem exatamente o que estão enaltecendo ou censurando (DWORKIN, 2000, p. 2). A prometida comunhão axiológica em torno da promoção de uma sociedade livre, justa e solidária - Constituição Federal, art. $3^{\circ}$, I (BRASIL, 1988) - é ilusão que não transcende os limites da superficialidade, pois, a partir do instante em que são debatidos instrumentos específicos de concretização do preceito constitucional, proliferam as divergências.

Historicamente, o sexo teve grande relevância no papel conferido aos atores sociais, de modo que o acidente do cromossomo X ou Y era capaz de selar a sorte e o destino laboral de uma pessoa por toda a sua existência. Sob o signo da diferença de gênero que deveras pode justificar - em alguns casos - o tratamento distinto como forma de corrigir discrepâncias a fim de fomentar a isonomia, promoveram-se as mais absurdas distorções para que fosse reservado ao homem o espaço público de provedor da subsistência material da família, ao passo que a mulher ficasse encarcerada no recinto privado dos afazeres domésticos e de procriação (WALLERSTEIN, 2001, p. 22-23). Em outras palavras, "a divisão sexual do trabalho estrutura as relações de gênero na sociedade e estabelece uma divisão naturalizada das áreas reprodutivas atribuídas às mulheres e das áreas produtivas atribuídas aos homens" (THOME, 2012, p. 119-120).

Esse discurso possui lastros jurídicos, filosóficos e religiosos bastante remotos e arraigados em quase todas as culturas, que são, em larga medida, responsáveis pela reprodução atávica de grande parte dos modelos atuais de relações de poder. O Código de Manu punha as mulheres sob o jugo dos homens durante toda a vida, declarava-as inclinadas a desgraçar

1 Constam da nota introdutória ao diploma hindu as seguintes informações: "Manu, progênie de Brahma, pode ser considerado como o mais antigo legislador do mundo; a data de promulgação de seu Código não é certa, alguns estudiosos calculam que seja aproximadamente entre os anos 1300 e 800 a.C. Lembramos que o Código de Hamurabi, mais antigo que o Código de Manu em pelo menos 1500 anos, não se trata de um verdadeiro código no sentido técnico da palavra, mas de uma coletânea de normas que abrange vários assuntos e preceitos" (CÓDIGO..., 2002, p. 41). 
suas famílias, designava-as aos ofícios do lar e à purificação do corpo e afirmava que sua felicidade suprema e respeito só eram alcançados mediante o casamento com a intenção de ter filhos. ${ }^{2}$ Aristóteles, por sua vez, apesar de defender a alternância de poder, a liberdade e a igualdade entre os homens - numa acepção que excluía os predestinados à escravidão -, foi categórico ao ressalvar que "quanto ao sexo, a diferença é indelével: qualquer que seja a idade da mulher, o homem deve conservar sua superioridade” (ARISTÓTELES, 2006, p. 33). Já a Bíblia responsabilizou diretamente a mulher pelo pecado original, mas estabeleceu sanções muito distintas em função das respectivas atribuições: a ela, a multiplicação das dores do parto e o domínio pelo homem, cujo flagelo foi o de abandonar o modo de vida puramente extrativista e dedicar-se ao trabalho árduo para a subsistência. ${ }^{3}$

O direito do trabalho sofreu influxos dessa concepção patriarcal de divisão das tarefas, trazendo vestígios significativos de discriminação. Basta ver que a Suprema Corte dos Estados Unidos, ao julgar o caso Bradwell v. The State - 83 U.S. 130 (EUA, 1872), afirmou a constitucionalidade de uma lei do estado de Illinois que vedada às mulheres o exercício da advocacia. Reproduzindo a pregação bíblica, decidiu-se que o dispositivo se conformava à Lei do Criador, segundo a qual o homem deveria ser o protetor da mulher, cuja timidez e delicadeza incompatibilizavam-na para o exercício de determinadas profissões e lhe atribuíam por missão suprema o cumprimento dos nobres e benignos ofícios de esposa e de mãe. ${ }^{4}$ Já às portas da década de 1950, a mesma Corte ratificaria - em Goesaert v. Cleary, 335 U.S. 464 (EUA, 1948) - a constitucionalidade de uma lei do estado de Michigan que proibia as mulheres

2 Nesse sentido, os arts. 420, 422, 428 e 443, verbis: "Art. 420. Uma mulher está sob a guarda de seu pai, durante a infância, sob a guarda de seu marido durante a juventude, sob a guarda de seus filhos em sua velhice; ela não deve jamais se conduzir à sua vontade. [...] Art. 422. Deve-se sobretudo cuidar e garantir as mulheres das más inclinações, mesmo as mais fracas; se as mulheres não fossem vigiadas, elas fariam a desgraça de suas famílias. [...] Art. 428. Que o marido designe para função à sua mulher a receita das rendas e a despesa, a purificação dos objetos e do corpo, o cumprimento de seu dever, a preparação do alimento e a conservação dos utensílios do lar. [...] Art. 443. As mulheres que se unem a seus esposos no desejo de ter filho que são perfeitamente felizes, dignas de respeito e que fazem a honra de suas casas, são verdadeiramente as Deusas da fortuna; não há diferença” (CÓDIGO..., 2002, p. 89-91).

3 Em Gênesis 3,16-20, lê-se: “16. À mulher, ele declarou: 'Multiplicarei grandemente o seu sofrimento na gravidez; com sofrimento você dará à luz filhos. Seu desejo será para o seu marido, e ele a dominará'. 17. E ao homem declarou: 'Visto que você deu ouvidos à sua mulher e comeu do fruto da árvore da qual ordenei a você que não comesse, maldita é a terra por sua causa; com sofrimento você se alimentará dela todos os dias da sua vida. 18. Ela lhe dará espinhos e ervas daninhas, e você terá que alimentar-se das plantas do campo. 19. Com o suor do seu rosto você comerá o seu pão, até que volte à terra, visto que dela foi tirado; porque você é pó, e ao pó voltará”" (BÍBLIA, 2000).

4 A decisão - lavrada pelo Justice Miller - foi tomada por 8 votos a 1, tendo sido consignado que a harmonia e a identidade da família repugnavam a ideia de a mulher adotar uma carreira distinta e independente do marido. Como num sermão eclesiático, ele declarou: "The civil law, as well as nature herself, has always 
de trabalharem em bares. Sob a ferrenha ideologia de controle absoluto sobre a conduta feminina preconizada pelo Código de Manu, manteve-se a lei ao argumento de que as vastas transformações na posição social da mulher não obstavam a demarcação - pelo Estado - de uma fronteira clara entre os sexos no que dizia respeito ao comércio de bebidas alcoólicas. ${ }^{\mathbf{5}}$

Mas não foi apenas no plano internacional que o machismo deixou cicatrizes nas relações de trabalho. Para perplexidade da doutrina brasileira (MALLET, 2013, p. 37), esteve em vigor até $1989^{6}$ o art. 446 da Consolidação das Leis do Trabalho (CLT), cujo parágrafo único outorgava ao marido a prerrogativa de pleitear judicialmente a rescisão do contrato de trabalho quando a sua continuação fosse "suscetível de acarretar ameaça aos vínculos da família ou perigo manifesto às condições peculiares da mulher"7 (BRASIL, 1943), ou seja, prejudicasse os afazeres domésticos. Seguindo a filosofia aristotélica de supremacia eterna do macho sobre a fêmea, o dispositivo reforçava o papel da mulher de cuidar da família e o do homem - naturalmente sobranceiro - de zelar para que a mulher assim o fizesse.

\section{A “INTRUSÃo” DA MULHER NO MERCADO DE TRABALHO E AS ESTRUTURAS PATRIARCAIS DE PODER}

A ruptura paradigmática do monopólio masculino da vida em sociedade constituiu uma espécie de rebeldia inconveniente a deturpar os antigos alicerces de segmentação das atribuições, os quais encarceravam a mulher no "segmento privado", expressão que guarda evidente sinonímia à privação de todas as relações sociopolíticas (GUERRA, 2011, p. 73). Não

recognized a wide difference in the respective spheres and destinies of man and woman. Man is, or should be, woman's protector and defender. The natural and proper timidity and delicacy which belongs to the female sex evidently unfits it for many of the occupations of civil life. [...] The harmony, not to say identity, of interest and views which belong, or should belong, to the family institution is repugnant to the idea of a woman adopting a distinct and independent career from that of her husband. [...] The paramount destiny and mission of woman are to fulfill the noble and benign offices of wife and mother. This is the law of the Creator".

5 Confira-se, a propósito, que não obstante os cerca de três milênios que separam o diploma hindu e a decisão estadunidense, a lógica de dominação é praticamente idêntica, como demonstra o art. 430, verbis: "Art. 430. Beber licores inebriantes, frequentar má companhia, separar-se de seu esposo, correr de um lado e de outro, entregar-se ao sono em horas indevidas e ficar em casa de outra, são seis ações desonrosas para mulheres casadas" (CÓDIGO..., 2002, p. 90).

6 O dispositivo em questão foi revogado pela Lei n. 7.855/89 (BRASIL, 1989).

7 O artigo em questão possuía o seguinte teor: “Art. 446. Parágrafo único. Ao marido ou pai é facultado pleitear a rescisão do contrato de trabalho, quando a sua continuação for suscetível de acarretar ameaça aos vínculos da família, perigo manifesto às condições peculiares da mulher ou prejuízo de ordem física ou moral para o menor”. 
foi por acaso que Olympe de Gouges (1793), depois de propor a Declaração Universal dos Direitos da Mulher e da Cidadã ${ }^{8}$ - em resposta ao documento autointitulado universal e contraditoriamente dirigido apenas aos homens em sentido estrito -, foi cruelmente assassinada na guilhotina (BEAUVOIR, 1970, p. 142).

Portanto, numa história que continua a ser escrita, a subversão política decorrente da ocupação do espaço produtivo pelas mulheres ainda é paulatina e impregnada de ranços que a vinculam ao cuidado com a prole e à execução dos afazeres domésticos, seja de forma gratuita, seja mediante contraprestação (MELO, 1998). Essa hipótese pode ser testada atualmente sob três frentes: i) quem exerce o trabalho doméstico remunerado; ii) quem exerce o trabalho doméstico não remunerado; e iii) quem é incumbido pelo Estado de criar os filhos.

No que concerne à primeira delas, convém lembrar que a colocação feminina no mercado não eliminou miraculosamente os penosos trabalhos domésticos, tampouco contou com a generosa colaboração masculina para dividir sua execução. Numa moldura bem menos quimérica, sucedeu a criação de uma nova categoria de trabalhadores - os domésticos -, desprezados socialmente e precarizados legalmente, que permitiu às mulheres com maior renda pessoal ou familiar transferir os deveres de casa para outras mais pobres, na chamada polarização do trabalho feminino (HIRATA; KERGOAT, 2008, p. 263-278). Para um grande contingente operário feminino, operou-se a mera transmutação do perfil de criadas para o de trabalhadoras, ${ }^{9}$ com dados de meados da década de 1990 a revelar um percentual de 93,16\% de mulheres exercendo o trabalho doméstico remunerado. ${ }^{10}$

A delegação das atribuições caseiras para mulheres menos favorecidas equacionou apenas uma parcela dos problemas das mais privilegiadas, pois, apesar de até 2013, inacreditavelmente, não haver limitação à jornada das trabalhadoras e trabalhadores domésticos, ${ }^{11}$ era impossível constrangê-los à realização de todas as tarefas, o que deixava resquícios de serviços caseiros a serem feitos pelo casal. Nesse contexto, mesmo quando ambos exercem atividades econômicas,

8 No documento, Olympe de Gouges reivindicava direitos simétricos aos dos homens e a abolição de privilégios masculinos.

9 Numa abordagem que também contempla a questão racial, Melo diz que "no Brasil as negras passaram diretamente da senzala para o trabalho doméstico" (MELO, 1998, p. 8).

10 Os dados da participação segundo o sexo no serviço doméstico remunerado foram obtidos da Pesquisa Nacional por Amostra de Domicílios (PNAD), realizada pelo IBGE, em 1995. As estatísticas só não são ainda mais acachapantes pelo fato de a função de Atendente/Jardineiro/Motorista ser preponderantemente ocupada por homens $(79,08 \%)$. Todavia, algumas funções, como as de Lavadeira/Passadeira, quase não possuem homens $(0,76 \%)$, a ponto de a gramática brasileira não conter denominações masculinas para tais ocupações (GUERRA, 2011, p. 73).

11 O que só passou a ocorrer no Brasil, ao menos no plano formal, com a promulgação da Emenda Constitucional n. 72, de 2 de abril de 2013 (BRASIL, 2013a). 
a divisão do remanescente doméstico nas próprias residências não é equânime, haja vista o fato de as mulheres trabalharem mais que o dobro em relação aos homens ${ }^{12}$ e em atividades menos nobres, mantendo, ainda assim, o status quo de "donas de casa" (MADALOZZO; MARTINS; SHIRATORI, 2010).

O último e quiçá mais polêmico aspecto a retratar o protagonismo masculino nas atividades resplandecentes do cenário mercantil em contraste à opacidade feminina no palco familiar (TEIXEIRA, 2010, p. 258) diz respeito à tutela conferida à maternidade. Malgrado o texto constitucional de 1988 seja expresso ao assegurar a igualdade entre os sexos (CF, art. $\left.5^{\circ}, \mathrm{I}\right)$, garante às mulheres 120 dias de licença-maternidade (CF, art. $7^{\circ}$, XVIII) e aos homens apenas 5 de licença-paternidade ( $\mathrm{CF}$, art. $7^{\circ}$, XIX, c/c art. 10, $\S 1^{\circ}$, ADCT), deixando patente que o cuidado operacional com os filhos é uma atribuição feminina por "excelência”. Tal circunstância opera impiedosamente em desfavor da mulher, ainda que o empregador seja neutro quanto ao sexo dos seus empregados, porquanto falta a ela uma qualificação relevante ao exercício da função, qual seja, a liberdade no que tange à incumbência de zelar pelos descendentes (KYMLICKA, 2006, p. 308-309).

A afirmação pode parecer ingênua e facilmente sobrepujável diante da objeção de que a licença-maternidade tem por escopo a recuperação física da mulher com os trabalhos envolvidos na reprodução (como, e.g., gravidez, parto e amamentação), que o homem deveras não tem. Todavia, o argumento revela apenas uma fração da realidade, já que o período também objetiva o reforço dos vínculos com o recém-nascido e a adaptação à nova realidade familiar. Ademais, ele se mostrava falacioso quando o legislador concedia apenas à empregada adotante que, por óbvio, não possui labor reprodutivo - a mesma licença dada à mãe biológica e, além disso, reservava-lhe um período de afastamento - ainda que inferior - mesmo nas adoções de crianças com até 8 anos de idade. ${ }^{13}$

Aludido dispositivo permite concluir que o objeto da proteção normativa não é apenas a gestante sob o aspecto biológico, mas a instituição familiar como um todo. ${ }^{14}$ Conquanto

Segundo dados de 2012 (IBGE, 2013, p. 165), enquanto os homens consomem cerca de 10,0 horas semanais nos afazeres domésticos, as mulheres gastam 20,8 horas semanais nas mesmas tarefas.

13 Dispunha o art. 392-A da CLT (BRASIL, 1943): “Art. 392-A. À empregada que adotar ou obtiver guarda judicial para fins de adoção de criança será concedida licença-maternidade nos termos do art. 392, observado o disposto no seu $\S 5^{\circ}$. $\S 1^{\circ}$ No caso de adoção ou guarda judicial de criança até 1 (um) ano de idade, o período de licença será de 120 (cento e vinte) dias. $\S 2^{\circ}$ No caso de adoção ou guarda judicial de criança a partir de 1 (um) ano até 4 (quatro) anos de idade, o período de licença será de 60 (sessenta) dias. § $3^{\circ}$ No caso de adoção ou guarda judicial de criança a partir de 4 (quatro) anos até 8 (oito) anos de idade, o período de licença será de 30 (trinta) dias. $\S 4^{\circ} \mathrm{A}$ licença-maternidade só será concedida mediante apresentação do termo judicial de guarda à adotante ou guardiã”.

De acordo com Silva (2009): "O primeiro aspecto é identificar qual é o objeto de proteção da norma, pois 
fosse válida a intenção, tinha como subproduto uma miríade de fontes discriminatórias pelo legislador: i) contra as mulheres, porquanto reiterava, a não mais poder, que só elas devem se afastar do trabalho para tomar conta dos filhos; ii) contra as estruturas familiares monoparentais masculinas - rectius, homens solteiros -, já que a teleologia normativa de suporte ao liame familiar lhes era solenemente desprezada; e iii) contra os homens homossexuais vinculados por união homoafetiva, pelo mesmo motivo indicado no item ii.

Uma parcela dessa anomalia foi corrigida em 2013 - ao menos em relação aos itens ii e iii -, com a extensão do direito ao empregado que adotar ou obtiver guarda judicial para tal fim. ${ }^{15}$ Manteve-se, contudo, o ultrapassado arquétipo de que, nos casais heterossexuais, salvo em caso de morte, literalmente, ${ }^{16}$ só a mulher alija-se do trabalho para atender a prole, ao contrário do que ocorre nos países nórdicos, em geral (FARIA, 2002, p. 179), e mais especificamente na Suécia (1995), onde o Parental Leave Act permite um sistema bastante flexível de compartilhamento da licença entre os pais.

\section{Abordagem de GÊNERO do ASSÉdio SEXUAl NO TRABALHO: VÍCIOS E VIRTUDES}

O sucinto escorço da justaposição das mulheres no mercado de trabalho demonstra que elas não foram e talvez ainda não sejam totalmente bem-vindas no ambiente laboral, pois a independência econômica alcançada pelo exercício de atividade produtiva desmonta o estado de sujeição aos homens e faz com que elas invadam um setor outrora exclusivo e compitam por posições de maior destaque. A assimilação dessa premissa sociológica faz com que se aquilate a possibilidade da configuração de ambientes de trabalho hostis, ofensivos e vexatórios, nos quais a ojeriza à companhia feminina é externada por diferentes manifestações que desdenham os propalados ideais de igualdade.

Ante tal quadro, o assédio sexual também pode ser epistemologicamente compreendido como forma de discriminação sexual, conforme expressamente reconhecido pela Diretiva

se o almejado é proteger a mulher-gestante, apenas do ponto de vista biológico, limita-se o escopo da norma à necessidade de proteção física e assim não haveria sentido conceder tal licença àquele que adota, uma vez que, neste caso, não há que se falar da necessidade desse tipo de proteção. Ocorre que o disciplinamento dado ao tema deixa claro que o objeto de proteção é a maternidade e esse fato redunda em uma série de consequências, como a necessidade de concessão de licença também aos pais, licença-paternidade, e o surgimento da licença-maternidade adotante, por exemplo”.

15 A retificação ocorreu com o advento da Lei n. 12.873, de 24 de outubro de 2013, que acresceu o art. 392-C à CLT, com a seguinte redação: "Art. 392-C. Aplica-se, no que couber, o disposto no art. 392-A e 392-B ao empregado que adotar ou obtiver guarda judicial para fins de adoção” (BRASIL, 2013b).

16 E não retoricamente, pois o art. 392-B da CLT, também acrescido pela Lei n. 12.873, de 24 de outubro de 2013, garante ao cônjuge ou companheiro supérstite o gozo do período restante de licença em caso de falecimento da mãe (BRASIL, 2013b). 
2002/73/CE do Parlamento Europeu (BÉLGICA, 2002). ${ }^{17}$ No âmbito latino-americano, a Costa Rica chegou à mesma conclusão, baseada nos princípios constitucionais de respeito pela liberdade e pela vida humana, do direito ao trabalho e de igualdade, bem como em documentos internacionais de combate à discriminação, ${ }^{18} \mathrm{com}$ destaque para a Convenção Interamericana para Prevenir, Sancionar e Erradicar a Violência contra a Mulher.

As asserções ora formuladas instigam refutações diante do seu caráter supostamente sectário, haja vista os homens também serem vítimas potenciais do assédio sexual (FELKER, 2010, p. 271-273), bem como o assédio não ser necessariamente dirigido às mulheres como gênero, e sim individualizado naquelas que, em tese, despertam maior atração sexual no ofensor. Em que pese as objeções não terem o condão de retirar integralmente a validade das conclusões apresentadas, merecem ser ponderadas a fim de que se possa aferir as condições para que elas se revelem corretas.

Em primeiro lugar, é de clamorosa obviedade que tanto homens quanto mulheres podem ser vítimas de assédio sexual, como deixava explícito o Decreto Real belga (BÉLGICA, 2002). ${ }^{19}$ Porém, se a hierarquia funcional possui alguma relevância na ocorrência do fenômeno, os relatos do Observatório Social, com base em pesquisa do Instituto Ethos/Ibope (SOUZA DIAS; CASARA; WERLE, 2004, p. 7), demonstram que: no Brasil, de cada 10 cargos executivos existentes nas grandes empresas, apenas 1 é ocupado por mulheres; no nível de gerência, 2 cargos são das mulheres e 8 dos homens; nas chefias, as mulheres são 3 e os homens, 7; as mulheres também estão em menor número no chão das fábricas e nos cargos funcionais e administrativos: 3,5 contra $6,5 .{ }^{20}$ Essa conjuntura de estratificação vertical dos empregos, aliada à

17 Que assim preconiza em seu art. 30, verbis: “3. Le harcèlement et le harcèlement sexuel au sens de la présente directive sont considérés comme une discrimination fondée sur le sexe et sont dès lors interdits”.

18 É o que se extrai do art. $1^{\circ}$ da Lei n. 7.476/95: “Artículo $1^{\circ}$. Principios regentes. Esta ley se basa en los principios constitucionales del respeto por la libertad y la vida humana, el derecho al trabajo y el principio de igualdad ante la ley, los cuales obligan al Estado a condenar la discriminación por razón del sexo y a establecer políticas para eliminar la discriminación contra la mujer, según la Convención de las Naciones Unidas sobre la eliminación de todas las formas de discriminación contra la mujer y la Convención interamericana para prevenir, sancionar y erradicar la violencia contra la mujer” (COSTA RICA, 1995).

19 O referido dispositivo legal, em seu art. 32-3, conceituava assédio sexual no trabalho como "toute forme de comportement verbal, non-verbal ou corporel de nature sexuelle, dont celui qui s' en rend coupable, sait ou devrait savoir, qu'il affecte la dignité de femmes et d'hommes sur les lieux de travail” (grifo nosso). O decreto foi revogado em 2007. Apesar de as demais legislações não terem o capricho de arrolar o sexo das possíveis vítimas, elas utilizam termos neutros como "pessoas” ou substantivos masculinos como "empregados ou trabalhadores", que, a toda evidência, podem ser utilizados para ambos os sexos.

20 A consolidação das informações tem por base uma pesquisa de 2003. Na pesquisa de 2010 (PUCCI, 2010, p. 7), apesar de não haver uma síntese tão didática e esclarecedora, os números absolutos comprovam que as coisas pouco mudaram. 
segregação horizontal (DRAPEAU, 1991, p. 22-23) - designação de atribuições de acordo com o sexo, relegando mulheres às funções em que se confundem tarefas profissionais com favores pessoais ${ }^{21}$-, fornecem o comburente e o combustível para a combustão de assédio que tem nas mulheres o grande público-alvo, superando os homens tanto em frequência quanto em gravidade (BELMONTE, 2013, p. 193). Não é por outra razão que os números (KAY;WEST, 2002, p. 765) denunciam o seguinte no que tange à incidência em relação ao gênero: a) homens assediando mulheres - 90\%; b) homens assediando homens - 9\%; c) mulheres assediando homens $-1 \%$.

Perante uma realidade tão avassaladora e inexpugnável, não há como tergiversar sobre o envolvimento da questão de gênero em diversas conjecturas de assédio sexual e tampouco quanto às mulheres serem as vítimas preferenciais. Outrossim, conforme mencionado alhures, o fato de apenas algumas delas serem assediadas não desnatura implacavelmente a intelecção acerca do preconceito sexual. A Suprema Corte do Canadá abordou com propriedade a questão no caso Jensy v. Platy Enterprises Ltd., [1989] 1 S.C.R. 1252, ao afirmar que a discriminação normalmente é composta de vários ingredientes que afetam de maneira distinta os membros de determinado grupo. ${ }^{22}$ Para a Corte, a questão fulcral residia no fato de o ofensor ser um empregado homem heterossexual e, portanto, somente as mulheres estarem sujeitas a esse tipo de comportamento agressivo.

Da mesma forma, a discriminação entre pessoas do mesmo sexo não afasta a hipótese de discriminação de gênero. Apesar de parecer contraintuitivo numa primeira impressão, nada sustenta a ilação de que o homem não discrimina os seus próprios pares, como teve a sagacidade de observar a Suprema Corte dos Estados Unidos em Oncale v. Sundowner Offshore Services, 523 U.S. $75 .{ }^{23} \mathrm{~A}$ despeito de ser reconhecidamente minoritária, a ocorrência de assédio

Tais como arrumadeiras, camareiras, enfermeiras, massoterapeutas, secretárias, recepcionistas etc.

22 Entre outras coisas, esclareceu-se que a eventual exigência de que a discriminação fosse perpetrada de modo absolutamente idêntico entre todas as empregadas esvaziaria por completo a proteção legislativa contra o assédio sexual: "Sexual harassment is a form of sex discrimination. [...] The fact that only some, and not all, female employees at the restaurant were subject to sexual harassment is not a valid reason to conclude that sexual harassment could not amount to discrimination on the basis of sex. Sex discrimination does not exist only where gender is the sole ingredient in the discriminatory action and where, therefore, all members of the affected gender are mistreated identically. [...] If a finding of discrimination required that every individual in the affected group be treated identically, legislative protection against discrimination would be of little or no value. [...] The crucial fact in this case is that it was only female employees who ran the risk of sexual harassment. Indeed, only a woman could be subject to sexual harassment by a heterosexual male, such as the offending employee" (grifo nosso).

23 O precedente foi muito importante pelo fato de a Suprema Corte escoimar categoricamente quaisquer dúvidas quanto à possibilidade de discriminação praticada por pessoas do mesmo sexo: "Title VII's prohibition of discrimination 'because of...sex' protects men as well as women, [...], and in the related context 
sexual entre pessoas do mesmo sexo existe, principalmente de homens contra outros homens pertencentes a determinados círculos, quais sejam os jovens, homossexuais, membros de minorias étnicas ou que trabalham em ocupações tidas como femininas (TOMEI; VEGA-RUIZ, 2007, p. 161).

Conquanto seja perspicaz o raciocínio da Suprema Corte norte-americana, ele denuncia a vulnerabilidade do argumento diante de assediantes bissexuais, razão pela qual a percepção mais arguta seria a de que existe discriminação desde que o ato seja praticado como instrumento de reafirmação de normas e estereótipos de gênero. A partir desse arquétipo, o assédio sexual teria preocupações atinentes à sexualidade e também à igualdade, em vez de ser apenas “algo que os homens fazem com as mulheres" (FRANKE, 2004, p. 179). Em síntese, embora as proteções desse jaez tenham como destinatário principal as mulheres, devem ser lidas de forma a tutelar todas as formas de discriminação contra os homens, conforme estabelece o Sex Discrimination Act da Inglaterra (1975). ${ }^{\mathbf{2 4}}$

Há outros pontos críticos em se levar ao paroxismo a ideia de que assédio sexual configura forçosamente preconceito de gênero. Se todas as formas de manifestação sexual forem avaliadas com suspeição, um dos possíveis efeitos colaterais é a criação de uma espécie de pânico nas relações interpessoais com o sexo oposto, aumentando a "segregação sexual" e tornando mais difícil às mulheres a conquista da igualdade no local de trabalho (CLARKE, 2007, p. 87). Para que se tenha uma noção da dimensão dessa "generofobia", estudiosos indicam a existência de uma "barreira de vidro" que ameaça relações amistosas e saudáveis entre os sexos, com $75 \%$ dos homens norte-americanos tendo declarado em uma pesquisa que se preocupam com assédio sexual sempre que interagem com mulheres no local de trabalho (ELSESSER; ANNE, 2006, p. 1090). Paradoxalmente, o alegado temor de acusações de assédio sexual - ainda que inverídico - poderia se transformar em utensílio de isolamento das mulheres sob um pretexto jurídico (QUINN, 2000, p. 1176), ou seja, operar-se-ia a metamorfose do assédio sexual em assédio moral, só que justificada pelo ordenamento.

Além disso, uma postura excessivamente zelosa dos empregadores a fim de coibir o assédio sexual pode implicar a violação de outros direitos fundamentais, tais como a liberdade de expressão (BROWNE, 1991, p. 481) e a intimidade, com empregadores proibindo relações

of racial discrimination in the workplace we have rejected any conclusive presumption that an employer will not discriminate against members of his own race [...]. If our precedents leave any doubt on the question, we hold today that nothing in Title VII necessarily bars a claim of discrimination 'because of . . . sex' merely because the plaintiff and the defendant (or the person charged with acting on behalf of the defendant) are of the same sex".

24 Que assim preconiza: "2. Sex Discrimination Against Men 2(1) Section 1, and the provisions of Parts II and III relating to sex discrimination against women, are to be read as applying equally to the treatment of men, and for that purpose shall have effect with such modifications as are requisite". 
íntimas entre seus empregados ${ }^{25}$ ou obrigando-os a declará-las (SCHULTZ, 1998). Outrossim, há quem diga que o banimento de condutas sexuais no trabalho encaixa-se como uma luva no projeto "neotaylorista" de aumentar a eficiência nos processos produtivos pela exclusão de comportamentos irracionais e emocionais, e a adaptação à lógica capitalista seria a explicação para os empregadores norte-americanos terem incorporado tão prontamente tais políticas (CLARKE, 2007, p. 88).

\section{A Construção CONCEITUAl diante da AMPlitude do Fenômeno}

Não é possível esboçar a definição de um instituto jurídico sem absorver todas as suas nuanças dimensionais, na medida em que a deficiência nessa captação deturpa a relação de simetria perfeita que deve existir entre continente e conteúdo. Nesse sentido, a legislação brasileira sobre assédio sexual foi das mais infelizes, desde a escolha topológica até sua limitada concepção. Circunscrito ao Código Penal, o dispositivo segue a lógica obtusa de hipertrofiar desnecessária e inconvenientemente ${ }^{26}$ o estatuto criminal com mais um delito de pequeno potencial ofensivo, solucionado - na melhor das hipóteses - com penas alternativas que só aumentam a sensação de impunidade do agressor em face de um "tipo penal morto" (MUÇOUÇAH, 2013, p. 713-714).

Se a opção de criminalizar o comportamento foi ruim, o delineamento dos seus contornos foi desastroso. Ao definir assédio sexual como o ato de "constranger alguém com o intuito de obter vantagem ou favorecimento sexual, prevalecendo-se o agente de sua condição de

25 Algumas empresas norte-americanas com filiais brasileiras estabeleciam tais espécies de vedação nos contratos de trabalho, as quais foram veementemente fustigadas pela jurisprudência brasileira, como demonstram os seguintes trechos desta ementa: "[...] A prática discriminatória costumeira, observada no procedimento adotado por várias empresas que, com base em normas de seu regulamento interno, dispensam empregados que namoram ou se casam, ou vedam a admissão de parentes de empregados, é atentatória ao princípio da igualdade de todos perante a lei, que encontra amparo em vários dispositivos do texto constitucional de 1988, erigido sobre o princípio da dignidade humana, fortemente enunciado nos diplomas que compõem o tecido do sistema de produção internacional dos direitos humanos. O art. $5^{\circ}$ assegura a igualdade de todos perante a lei, e o inciso XLI veda qualquer discriminação atentatória dos direitos e liberdades fundamentais, dentre eles a inviolabilidade da intimidade, vida privada, honra e imagem das pessoas, ficando o infrator sujeito ao pagamento da indenização pelo dano moral ou material decorrente de sua violação, nos termos do inciso X do mesmo artigo [...]” (RIO DE JANEIRO, 2004).

26 A catalogação criminal seria desnecessária por haver outras prescrições suficientes ao enquadramento do ofensor, tais como o constrangimento ilegal e a ameaça (MARZAGÃO JÚNIOR, 2006, p. 79-80), e inconveniente por afrontar o princípio da intervenção penal mínima ou da ultima ratio, segundo o qual a criminalização de determinada conduta só se legitima quando for o único meio de tutelar eficazmente determinado bem jurídico (BITENCOURT, 1996, p. 82). 
superior hierárquico ou ascendência inerentes ao exercício de emprego, cargo ou função" CP, art. 216-A (BRASIL, 1940), o legislador assumiu uma perspectiva duplamente reducionista: além de vislumbrá-lo apenas sob a ótica da obtenção de favores sexuais, confinou o tipo à hierarquia inerente às relações de trabalho lato sensu, algo sintomático de legislações arcaicas de parte da América do Sul, como, v.g., Argentina e Paraguai. ${ }^{27}$

No ambiente de trabalho, comportamentos sexuais indesejados não ocorrem somente entre os chefes e seus chefiados - manifestam-se de forma vertical (ascendente ou descendente) e horizontal (GOLDSTEIN, 2009, p. 120-121) - , tanto assim que, na França (1992) ${ }^{28}$ e na Espanha $^{29}$ (1995), essa circunstância constitui apenas uma das causas de aumento de pena.

Todavia, a falha mais gritante do Código Penal brasileiro foi defini-lo exclusivamente em função do suposto desejo de o ofensor obter uma recompensa sexual. A satisfação da lascívia mediante extorsão não é o único escopo das investidas sexuais, talvez nem sequer o principal (JAKUTIS, 2006, p. 176). Muitas vezes a intenção do agressor é puramente discriminatória, constitui violência de gênero no sentido de subjugar a mulher, externando a misoginia - ou a misantropia - a partir da criação de um ambiente inóspito no qual o recado que se pretende transmitir, ainda que inconscientemente, é o de que ela deveria permanecer na esfera privada de seu domicílio. Não por outra razão, entende a doutrina que “o assédio sexual não é mais do que uma evolução do assédio moral. Nos dois casos, trata-se de humilhar o outro e considerá-lo um objeto à disposição" (HIRIGOYEN, 2012, p. 100). Em sentido diametralmente oposto ao da discriminação de gênero, o diploma tupiniquim compreendeu o assédio sexual como singela manifestação isolada de indivíduos incontinentes que procuram tirar vantagens luxuriosas de seu alto cargo.

27 Ainda assim, a legislação brasileira parece ser a pior de todas, uma vez que a Argentina se limita a incluir o malfadado conceito como espécie do gênero coação e, ainda assim, restrito aos servidores da administração pública federal (ARGENTINA, 1993). Por outro lado, embora o Código paraguaio seja similar ao brasileiro no tocante ao conceito (art. 133), possui um sistema de composição mediante pagamento de uma soma à vítima para o reequilíbrio da paz social, tendo como parâmetro a situação econômica do devedor e sem excluir a demanda por perdas e danos (art. 59), ou seja, com características semelhantes aos punitive damages dos sistemas anglo-saxônicos (PARAGUAI, 1997). O Código do Trabalho do Chile constitui a honrosa exceção continental (CHILE, 2002).

28 O Código Penal francês aumenta a pena de 2 para 3 anos e a multa de 30.000 para 45.000 euros: "Article 222-33. [...] Ces peines sont portées à trois ans d'emprisonnement et $45000 €$ d'amende lorsque les faits sont commis: $1^{\circ}$ Par une personne qui abuse de l'autorité que lui confèrent ses fonctions; [...]".

29 Assim prescreve o diploma espanhol: "Artículo 184. 2. Si el culpable de acoso sexual hubiera cometido el hecho prevaliéndose de una situación de superioridad laboral, docente o jerárquica, o con el anuncio expreso o tácito de causar a la víctima un mal relacionado con las legítimas expectativas que aquélla pueda tener en el ámbito de la indicada relación, la pena será de prisión de cinco a siete meses o multa de 10 a 14 meses". 
Um exemplo bastante ilustrativo que escancara os dois equívocos do legislador nacional é o caso Jenson v. Eveleth Taconite Company, 97-1147, decidido pela Justiça Federal norte-americana, que o descreveu como uma longa, torturante e desafortunada história. Na metade da década de 1970, Louis Jenson começou a trabalhar nas jazidas de ferro da empresa e junto com outras mulheres - a enfrentar um ambiente inóspito que incluía comentários genéricos e individuais por parte de seus colegas no sentido de que ela não pertencia às minas, estava roubando o emprego dos homens ${ }^{30}$ e deveria permanecer em casa. Ademais, os homens colocaram material pornográfico nos veículos, elevadores, vestiários e armários femininos, refeitórios etc. Não bastasse o abuso verbal e visual, elas também foram fisicamente molestadas com toques, beijos, apalpadas e beliscões indesejados, além de casos mais graves como a tentativa de fazer sexo oral nas mulheres enquanto elas dormiam. Após uma reclamação de Jenson ao Departamento de Direitos Humanos de Minnesota, ela teve os pneus de seu carro furados. Diante das constantes pressões dos companheiros de trabalho sob a indiferença do empregador, ela se demitiu no início de 1992, tendo sido diagnosticada, logo em seguida, com estresse pós-traumático e depressão reativa.

Em 1988, entretanto, ela ajuizara uma ação que foi certificada, no ano de 1991, como uma class action (ação coletiva). A batalha judicial também foi longa e recheada de percalços. Na primeira parte do julgamento (1992), decidiu-se que a empresa falhou ao não tomar providências contra a discriminação. Na fase de quantificação dos danos (1995), o perito entregou um relatório no qual revelou detalhes íntimos da vida das empregadas e afirmou que elas sofriam de "transtorno de personalidade histriônica", ${ }^{31}$ arbitrando uma média de US \$ 10.000,00 a cada uma. O julgamento foi revertido pela Corte de Apelações do Oitavo Circuito no final de 1997, ${ }^{32}$ com a designação de novo júri para mensurar a indenização. Ao

30 Segundo Hirigoyen (2012, p. 99), "Na Itália, na Espanha e na América Latina, muitos homens consideram que cada mulher que trabalha é culpada por um desempregado entre os homens”.

31 Um parecer especialmente cruel para as pretensões das autoras, haja vista os critérios diagnósticos da patologia descritos no sítio eletrônico PsiqWeb: "Um padrão invasivo de excessiva emocionalidade e busca de atenção, que começa no início da idade adulta e está presente em uma variedade de contextos, como indicado por cinco (ou mais) dos seguintes critérios: (1) sente desconforto em situações nas quais não é o centro das atenções; (2) a interação com os outros frequentemente se caracteriza por um comportamento inadequado, sexualmente provocante ou sedutor; (3) exibe mudança rápida e superficialidade na expressão das emoções; (4) usa consistentemente a aparência física para chamar a atenção sobre si próprio; (5) tem um estilo de discurso excessivamente impressionista e carente de detalhes; (6) exibe autodramatização, teatralidade e expressão emocional exagerada; (7) é sugestionável, ou seja, é facilmente influenciado pelos outros ou pelas circunstâncias; (8) considera os relacionamentos mais íntimos do que realmente são" (PSIQWEB, 2014, grifo nosso).

32 Ao fustigar as conclusões do laudo pericial, a Corte entendeu que o perito havia deixado de sopesar as provas produzidas pelas autoras baseado unicamente em suas próprias noções preconcebidas acerca da 
final de 1998, pouco antes do início do julgamento, quinze mulheres fizeram acordo com o empregador pelo valor global de US\$3.500.000,00.

O precedente ganhou notoriedade pelo fato de ter sido a primeira class action por assédio sexual nos Estados Unidos, a ponto de se eternizar nas telas de Hollywood com o filme Terra fria. ${ }^{33}$ Mas a relevância acadêmica deveu-se ao fato de a Corte ter reconhecido o assédio sexual como uma manifestação discriminatória sob a vertente da criação de uma atmosfera de intimidação, bem como por ter acolhido a possibilidade da prática pelos colegas de trabalho sem ascensão hierárquica, duas singularidades completamente desprezadas pelo Código Penal brasileiro.

Quanto ao primeiro aspecto, a definição do Código do Trabalho de Portugal (2009) demonstra que o legislador lusitano explorou, com muito mais ênfase, essa hipótese. ${ }^{34}$ De modo similar, a Itália (2005) considerou sexualmente discriminatórias as condutas indesejadas de cunho sexual que tenham por objetivo ou efeito a violação da dignidade de uma trabalhadora ou de um trabalhador ou criem um clima intimidatório, hostil, degradante, humilhante ou ofensivo. ${ }^{35}$ Existe, é claro, o assédio sexual denominado "quid pro quo" - "isto por aquilo" (BARROS, 1998, p. 1468) -, em que o ofensor utiliza o poder hierárquico a fim de humilhar a vítima com atos que dão a entender que sua liberdade sexual é moeda de troca, e a ascensão profissional ou a própria permanência no emprego só são obtidos mediante concessões dessa

prova psiquiátrica: "The record strongly suggests the Special Master foreclosed consideration of the evidence based on his own preconceived notions relating to psychiatric proof”.

33 O título original é North Country, uma película norte-americana de 2005 dirigida por Niki Caro, que conta o drama de Louis Jenson - interpretada por Charlize Teron - e sua batalha judicial contra a Jenson Eveleth Company.

34 Considerada uma das legislações mais modernas do mundo em termos trabalhistas, o Código do Trabalho português trata do assédio lato sensu em um único artigo, distinguindo o assédio sexual unicamente em face do caráter sexual da conduta: "Artigo $29^{\circ}$ Assédio. 1 - Entende-se por assédio o comportamento indesejado, nomeadamente o baseado em factor de discriminação, praticado aquando do acesso ao emprego ou no próprio emprego, trabalho ou formação profissional, com o objectivo ou o efeito de perturbar ou constranger a pessoa, afectar a sua dignidade, ou de lhe criar um ambiente intimidativo, hostil, degradante, humilhante ou desestabilizador. 2 - Constitui assédio sexual o comportamento indesejado de carácter sexual, sob forma verbal, não verbal ou física, com o objectivo ou o efeito referido no número anterior”.

Essa determinação foi trazida ao ordenamento jurídico pelo Decreto Legislativo 145/2005 - promulgado sob declarada influência da Diretiva Europeia 2002/73/CE -, com a seguinte redação: "2-ter. Sono, altresì, considerate come discriminazioni le molestie sessuali, ovvero quei comportamenti indesiderati a connotazione sessuale, espressi in forma fisica, verbale o non verbale, aventi lo scopo o l'effetto di violare la dignità di una lavoratrice o di un lavoratore e di creare un clima intimidatorio, ostile, degradante, umiliante o offensivo". 
natureza. O Código Federal dos Estados Unidos (2009) dimensiona as duas acepções do assédio, considerando-as expressões da violência de gênero, espécies de discriminação por causa do sexo, ${ }^{36}$ tanto assim que os mesmos princípios envolvidos são válidos para questões referentes à cor, à raça, à religião ou à nacionalidade. A Suprema Corte estadunidense reconheceu ambas em Meritor Savings Bank v.Vinson - 477 U.S. $57 .{ }^{37}$ As diferenças entre elas estão didaticamente explicitadas no Código do Trabalho francês, segundo o qual tanto propostas e comportamentos reiterados de conotação sexual que atentem contra a dignidade do trabalhador, em razão de sua conotação degradante ou humilhante, ou criem uma situação intimidatória, hostil ou ofensiva $\left(1^{\circ}\right)$, quanto as formas de pressão grave, ainda que não repetitivas, com o objetivo real ou aparente de obter um favor de natureza sexual em proveito do autor ou de terceiros $\left(2^{\circ}\right)$ constituem assédio sexual (FRANÇA, 2008).

Os textos europeus apontam uma discreta - porém significativa - diferença em relação à abordagem norte-americana, qual seja, a de não vincular o assédio sexual infalivelmente à discriminação, abrindo um horizonte pelo princípio da dignidade humana, como, aliás, já assinalava a Diretiva Europeia 2002/73 / CE (BÉLGICA, 2002). ${ }^{\mathbf{3 8}}$ Tal forma de enfrentamento possui claras vantagens pelo fato de prescindir da prova de um tratamento diferenciado entre os sexos, da conexão com gênero ou com eventuais motivos discriminatórios, focando suas atenções na natureza e nos efeitos da conduta (CLARKE, 2007, p. 102). A desvantagem reside no perigo de o conceito de dignidade ser tão amplo a ponto de se tornar virtualmente destituído

Os itens 1 e 2 descrevem o chamado "assédio sexual por chantagem" ou "quid pro quo" e o item 3, o "assédio sexual por intimidação" ou "ambiente hostil”: "§ 1604.11 Sexual harassment (a) Harassment on the basis of sex is a violation of section 703 of title VII. Unwelcome sexual advances, requests for sexual favors, and other verbal or physical conduct of a sexual nature constitute sexual harassment when (1) submission to such conduct is made either explicitly or implicitly a term or condition of an individual's employment, (2) submission to or rejection of such conduct by an individual is used as the basis for employment decisions affecting such individual, or (3) such conduct has the purpose or effect of unreasonably interfering with an individual's work performance or creating an intimidating, hostile, or offensive working environment".

37 O caso é intrigante e complexo por diversos aspectos, notadamente pelo fato de a vítima ter cedido às propostas sexuais diante do medo de perder o emprego, mantendo relações sexuais com o ofensor por cerca de quarenta a cinquenta vezes ao longo de alguns anos. Além disso, restou incontroverso que toda a progressão em sua carreira fora baseada unicamente no critério de mérito, bem como que os ataques cessaram após a vítima ter se engajado em um namoro firme.

Não obstante tal documento considere o assédio sexual como discriminação baseada em sexo (vide nota 17), conceitua-o também como o comportamento que tenha por objetivo ou por efeito afrontar a dignidade da pessoa: “'harcèlement sexuel': la situation dans laquelle un comportement non désiré à connotation sexuelle, s'exprimant physiquement, verbalement ou non verbalement, survient avec pour objet ou pour effet de porter atteinte à la dignité d'une personne et, en particulier, de créer un environnement intimidant, hostile, dégradant, humiliant ou offensant". 
de significado $^{39}$ ou tão abrangente que provoque ridículo (CLARKE, 2007, p. 97). Isso porque não há uma única prerrogativa baseada na "indignidade da pessoa humana", de modo que sua invocação universal é, em certa medida, inútil, porque grande parte das colisões se reduz, em última análise, a um conflito entre dignidades opostas (SCHREIBER, 2007, p. 171). Assim, a dignidade deixa de ser um "princípio-guia” das decisões para ser apenas uma forma de racionalização a justificar quaisquer resultados almejados, ou seja, transforma-se numa espécie de "Emplasto Brás Cubas"40 das ciências jurídicas, tudo o mais sendo supérfluo diante da panaceia que é afirmar a primazia de uma dignidade sobre as demais.

Quanto ao reconhecimento do assédio sexual horizontal, sua importância está umbilicalmente vinculada à responsabilização do empregador em face dos atos ilícitos praticados por seus empregados ${ }^{41}$ haja vista o direito de todos eles a um ambiente livre de assédio sexual, como determina, e.g., o art. 247.2 do Código do Trabalho canadense (CANADÁ, 1985). ${ }^{42} \mathrm{Tal}$ prerrogativa decorre de uma percepção ainda mais abrangente, qual seja, a de que os seres humanos ocupam o centro das preocupações relacionadas ao desenvolvimento sustentável, tendo direito a uma vida saudável, produtiva e harmônica com a natureza. De viés antropocêntrico, esse postulado - erigido à condição de princípio na Declaração do Rio sobre Meio Ambiente (ONU, 1992) - agrega o imperativo categórico segundo o qual todo indivíduo é um fim em si mesmo, e não um meio para consecução das finalidades alheias, sujeito e não objeto de direito (KANT, 2007, p. 69). Noutro vértice, não olvida que a saúde é a maior riqueza da humanidade, especialmente a dos trabalhadores, já que os demais valores materiais e espirituais são criados por eles através do seu trabalho (ROSHCHIN, 1974, p. 249).

Tais aforismos justificam a preocupação do constituinte brasileiro em garantir a todas as gerações - presentes e futuras - um meio ambiente sadio e equilibrado e, especialmente,

39 A biografia do Justice Brennan (STERN; WERMIEL, 2010, p. 419) informa que a Warren Court invocou a dignidade da pessoa humana em assuntos envolvendo pelo menos sete Emendas Constitucionais, mas raramente forneceu algum parâmetro alusivo ao significado da expressão.

40 A metáfora está relacionada ao consagrado romance Memórias póstumas de Brás Cubas, de Machado de Assis, que conta a história de Brás Cubas, um "defunto-autor" que faz sua autobiografia. O "Emplasto Brás Cubas” era uma espécie de remédio que curaria todas as doenças da humanidade e daria ao personagem fama e fortuna. A ironia é que ele contrai pneumonia ao tomar chuva e falece quando a mirabolante panaceia ainda era apenas um projeto, impedindo-o de alcançar o panteão da glória. Disponível em: <http://www.dominiopublico.gov.br/download/texto/bn000167.pdf>. Acesso em: 27 jan. 2014.

41 Em Jenson v. Eveleth Taconite Company (EUA, 1997), o fundamento legal para a condenação punitiva do empregador foi a Seção 549.20 do Minnesota Statutes, que estabelece as hipóteses em que o empregador pode ser responsabilizado (MINNESOTA, 2013).

42 O Estatuto Laboral canadense assim disciplina: "247.2. Every employee is entitled to employment free of sexual harassment”. 
a inclusão do meio ambiente de trabalho no conceito de meio ambiente geral - CF, arts. 225, caput c/ c 200, VIII (BRASIL, 1988). Trata-se de uma espécie de "direito intergeracional” ao desenvolvimento sustentável, ${ }^{43}$ do qual se deflui o dever de o empregador zelar por um ambiente de trabalho salubre inclusive do ponto de vista mental, ${ }^{44}$ sob pena de indenizar todos os danos causados. ${ }^{45}$ Um local de relações interpessoais contaminadas produz uma legião de incapazes acometidos de doenças profissionais, que aumenta vertiginosamente os custos da Previdência Social, numa geração de externalidade ${ }^{46}$ que não pode ser aceita como custo social legitimado no discurso desenvolvimentista. Por isso, o assédio sexual também deve ser encarado como um problema de saúde laboral (CRUZ PÉREZ, 2007) e sua prevenção intimamente ligada ao conceito de meio ambiente do trabalho saudável (LIMA, 2011, p. 172), que atenue ao máximo os "riscos psicossociais" (ANTONMATTEI et al, 2010, p. 16-17).

Tendo em vista que o assédio sexual afeta o bem-estar psicofísico e a serenidade dos trabalhadores, a Corte de Cassação italiana decidiu que ele comporta uma obrigação de tutela por parte do empregador. ${ }^{47}$ Numa perspectiva mais ampla, isso implica o ônus de tomar medidas para prevenir o assédio sexual não apenas dos colegas de trabalho, mas também de terceiros como clientes, consumidores e outros contatos comerciais, nos termos do Employment

43 O Código Ambiental italiano esclarece que é preciso satisfazer as necessidades das gerações atuais sem comprometer a qualidade de vida e as possibilidades das gerações futuras: "Art. 3-quater. (1) Principio dello sviluppo sostenibile. Ogni attivita' umana giuridicamente rilevante ai sensi del presente codice deve conformarsi al principio dello sviluppo sostenibile, al fine di garantire che il soddisfacimento dei bisogni delle generazioni attuali non possa compromettere la qualita' della vita e le possibilita' delle generazioni future" (ITÁLIA, 2006).

44 No meio acadêmico, esse dever foi consolidado no Enunciado n. 39 da $1^{\text {a }}$ Jornada de Direito Material e Processual na Justiça do Trabalho (BRASIL, 2007).

45 Não obstante a desnecessidade da existência de danos psicológicos à vítima para a configuração do assédio sexual - conforme unanimemente decidido pela Suprema Corte dos Estados Unidos em Harris v. Forklift Systems, Inc. - 510 U.S. 17 (EUA, 1993) -, a reparação deve abranger os danos biológicos, morais e existenciais (ITÁLIA, 2010).

46 A externalidade é conceituada como o ato de alguém que afeta o bem-estar de outrem (SHAVELL, 2004, p. 77).

47 Aludida obrigação consta do art. 2.087 do Código Civil italiano e serviu para justificar, no caso, a dispensa por justa causa de um empregado que cometera assédio, sem embargo da ausência de previsão específica no código disciplinar: "Le molestie sessuali sul luogo di lavoro, incidendo sulla salute e la serenità (anche professionale) del lavoratore, comportano l’obbligo di tutela a carico del datore di lavoro ai sensi dell'art. 2087 c.c..; deve ritenirse pertanto legitimo il licenziamento irrogato a dipendente que che abbia molestato sessualmente una colega sul luogo di lavoro, a nulla rilevando la mancata previsione della suddeta ipotesi nel codice disciplinaire [...]” (ITÁLIA, 1942). 
Equality Act 1998 irlandês (IRLANDA, 2012). Hipoteticamente, caso o empregador determine às empregadas que trabalhem em trajes excessivamente curtos ou decotados e disso resultem cortejos indesejados de terceiros, será responsabilizado pelo assédio sexual, exceto se as vestimentas sumárias forem imprescindíveis ao exercício da função. ${ }^{48}$ Mutatis mutandis, foi o que ocorreu na ocasião da fatídica campanha publicitária de uma grande loja de departamentos cujo bordão era “Quer pagar quanto?” e um dos slogans dizia “Olhou, levou!". As vendedoras tinham que usar broches que continham esses dizeres ambíguos, o que as tornava mais suscetíveis aos gracejos e galanteios abjetos de cunho sexual por parte dos fregueses, levando a jurisprudência a reconhecer a violação de seu patrimônio imaterial. ${ }^{49}$

\section{ReQuisitos À CONFIGURAÇÃo DO ASSÉDio SEXUAL}

Não obstante seja louvável a promulgação de uma legislação específica e detalhada acerca do assédio sexual no trabalho, sua ausência não compele os juízes trabalhistas a adotarem a visão acanhada do art. 216-A do Código Penal no afã de prestar a tutela civil e trabalhista (PAMPLONA FILHO, 2001, p. 53), tampouco serve de escusa à letargia jurisdicional. Além de o ordenamento pátrio possuir diversas ferramentas capazes de equacionar as demandas de forma satisfatória, o art. $8^{\circ}$ da CLT possibilita a adoção do direito comparado para preencher eventuais lacunas, e o direito estrangeiro é pródigo em leis, precedentes judiciais, convenções e tratados internacionais sobre o tema. Prova disso advém do paradigmático acórdão do Tribunal Superior do Trabalho (TST), de 17 de dezembro de 2013, no qual a Corte brasileira não apenas reconheceu o assédio sexual por intimidação, como também firmou o nexo causal entre a doença adquirida pelo trabalhador e o meio ambiente laboral, caracterizando-a, assim, como acidente do trabalho (BRASIL, 2013c). ${ }^{\mathbf{5 0}}$

48 Como, v.g., no caso de modelos que fazem campanhas publicitárias de peças íntimas. Por conta dessas peculiaridades, é pertinente a determinação do U.S. Code no sentido de avaliar o assédio como um todo, diante do conjunto de circunstâncias e no contexto em que ocorreu: "\$ 1604.11 - Sexual harassment. (b) In determining whether alleged conduct constitutes sexual harassment, the Commission will look at the record as a whole and at the totality of the circumstances, such as the nature of the sexual advances and the context in which the alleged incidents occurred" (EUA, 2009).

49 Confira-se, a propósito, o seguinte acórdão carioca que abordou o tema: "INDENIZAÇÃO POR DANO MORAL - CASA BAHIA USO DE BROCHE - A obrigatoriedade do uso de broches com dizeres que dão margens a comentários desrespeitosos por parte de clientes e terceiros configura violação do patrimônio imaterial do empregado" (RIO DE JANEIRO, 2011).

50 No caso, o preposto da empresa fazia constantes provocações insinuando a homossexualidade do trabalhador. Em razão disso, ele passou a ter, entre outros sintomas, fortes quadros álgicos, insônia, tremores, tiques nervosos e dificuldades na fala, sendo diagnosticado como portador de Transtorno Obsessivo 
Da mesma forma, a Índia (1997) forneceu um bom exemplo de pró-atividade ao julgar o caso Vishaka v. State of Rajasthan, mesmo porque o país possui um arcabouço legislativo mais propício a esse tipo de postura - ao menos no topo da pirâmide do Poder Judiciário -, haja vista a atribuição conferida à Suprema Corte de assegurar o cumprimento de direitos fundamentais pela expedição de instruções e diretivas com efeito vinculante sobre as demais cortes jurisdicionais. ${ }^{\mathbf{5 1}} \mathrm{O}$ caso indiano tratava-se de uma class action movida por ONGs e ativistas de movimentos sociais com o objetivo de implementar o direito fundamental à igualdade de gênero, tendo como causa próxima o estupro coletivo de uma assistente social pelo fato de ela ter barrado o casamento de uma criança. O crime sexual em si foi objeto de uma ação apartada, restringindo a agenda da Suprema Corte à edificação de mecanismos contra o assédio sexual em razão da ausência de provisões legislativas. Entre tantas questões abordadas, destacam-se o reconhecimento das obrigações do empregador de prevenir e coibir o assédio, a dupla abrangência de sua definição e o regramento das ações disciplinares. ${ }^{\mathbf{5 2}}$

A missão de preencher o hiato legislativo quanto aos requisitos à configuração do assédio sexual torna-se mais factível depois de esquadrinhadas suas diretrizes conceituais. Desse modo, a incorporação dos dois sentidos do fenômeno - por chantagem e por intimidação favorece a conclusão acerca da necessidade ou não de reiteração do comportamento do ofensor, embora não seja capaz de solucionar definitivamente a controvérsia.

Observe-se que o Código Penal francês distingue a necessidade ou não do requisito da continuidade de acordo com a espécie de assédio (FRANÇA, 1992). Conforme esse código, se a conduta for caracterizada por atos que violem a dignidade da pessoa em consequência de seu caráter humilhante, degradante ou da criação de um ambiente hostil, ofensivo ou

Compulsivo (TOC). Apesar de não ser uma patologia tipicamente ocupacional, a Corte entendeu que fora adquirida em função de ambiente de trabalho inadequado e hostil. Nesse ponto, assim ficou ementado o voto: "Sendo incontroverso nos autos que a psicopatologia (Transtorno Obsessivo-Compulsivo) do reclamante foi adquirida em função da atividade exercida em ambiente de trabalho inadequado e hostil, assim configurado pela prática de assédios moral e sexual por um dos prepostos da reclamada (subgerente), certo fica que a doença resulta das condições especiais do ambiente em que o trabalho é executado, equiparando-se, nos termos do artigo 20, $\S 2^{\circ}$, da Lei n. 8.213/91, a acidente do trabalho”.

51 Além, é claro, das clássicas ações constitucionais. Esse poder consta da combinação dos arts. 32 e 141 da Constituição do país, cujo teor é o seguinte: "32. Remedies for enforcement of rights conferred by this Part. (1) The right to move the Supreme Court by appropriate proceedings for the enforcement of the rights conferred by this Part is guaranteed. (2) The Supreme Court shall have power to issue directions or orders or writs, including writs in the nature of habeas corpus, mandamus, prohibition, quo warranto and certiorari, whichever may be appropriate, for the enforcement of any of the rights conferred by this Part" (ÍNDIA, 1949, grifo nosso).

Vale ressaltar, entretanto, que, desde 23 de abril de 2013, a Índia possui legislação federal específica concernente ao assédio sexual, denominada Sexual Harassment of Women at Workplace (Prevention, Prohibition and Redressal) Act (ÍNDIA, 2013). 
intimidatório, a continuidade é necessária. Por outro lado, se o comportamento constituir pressão grave com o objetivo real ou aparente de obter favores sexuais, um ato pode bastar para configurá-lo. ${ }^{53}$ Em sentido oposto, o Código Penal espanhol, ao criminalizar o assédio sexual - ali definido como a solicitação de préstimos sexuais no âmbito laboral que provoque na vítima uma situação objetivamente grave e humilhante, ou seja, numa concepção mais próxima do assédio por chantagem - exige que a prática seja “continuada ou habitual”54 (ESPANHA, 1995).

É manifesto o equívoco do diploma espanhol, haja vista uma única investida do ofensor contra a vítima ser potencialmente apta à caracterização do assédio, a depender da gravidade do ato reprochado (NASCIMENTO, 2015, p. 80). Foi exatamente isso que decidiu o Employment Appeal Tribunal no caso Bracebridge Engineering Ltd v. Darby. O precedente inglês teve como pano de fundo o infausto episódio envolvendo a Sra. Darby, empregada da Bracebridge que terminava seu expediente às 4h30min. No dia 25 de novembro de 1987, quando o relógio avançava pouco além das $4 \mathrm{~h} 15 \mathrm{~min}$, ela deixou seu posto de trabalho para tirar as luvas, lavar as mãos e aprontar-se para ir embora. No caminho, foi interceptada pelos Srs. Smith e Daly - encarregados de zelar pelo cumprimento da jornada -, que lhe disseram que ela não podia ir à cantina. Quando ela negou que iria até lá, eles a agarraram pelas pernas e braços e a levaram ao escritório do Sr. Daly. Ela pôde ficar em pé antes que eles adentrassem a sala. Naquele momento, o Sr. Daly apagou as luzes e colocou as pernas dela ao redor de seu corpo. Em seguida, ela se desvencilhou da posição e tentou ficar em pé, mas o Sr. Daly a ameaçou com uma advertência por tentar sair mais cedo do serviço. Ela negou a acusação, ao que foi apalpada em suas partes íntimas e recebeu um comentário grotesco. Após, ela conseguiu abrir a porta e saiu correndo. No dia seguinte, prestou queixa à Sra. Reynolds, que, após uma breve investigação, decidiu que nada havia a ser feito diante da negativa dos agressores. Então, a Sra. Darby ficou insatisfeita com o desfecho do caso e decidiu que aquilo lhe dava o direito de se demitir e receber a indenização como se fosse dispensada ("constructive

53 Em franca harmonia com as prescrições do Código do Trabalho, rege o estatuto criminal francês que: “Article 222-33. I - Le harcèlement sexuel est le fait d'imposer à une personne, de façon répétée, des propos ou comportements à connotation sexuelle qui soit portent atteinte à sa dignité en raison de leur caractère dégradant ou humiliant, soit créent à son encontre une situation intimidante, hostile ou offensante. II. Est assimilé au harcèlement sexuel le fait, même non répété, d'user de toute forme de pression grave dans le but réel ou apparent d'obtenir un acte de nature sexuelle, que celui-ci soit recherché au profit de l'auteur des faits ou au profit d'un tiers" (grifo nosso).

54 A redação original assim descreve o tipo: "Del acoso sexual. Artículo 184.1. El que solicitare favores de naturaleza sexual, para sí o para un tercero, en el ámbito de una relación laboral, docente o de prestación de servicios, continuada o habitual, y con tal comportamiento provocare a la víctima una situación objetiva y gravemente intimidatoria, hostil o humillante, será castigado, como autor de acoso sexual, con la pena de prisión de tres a cinco meses o multa de seis a 10 meses" (grifo nosso). 
dismissal"55). Ao apreciar a questão, o Tribunal entendeu que um único ato de assédio sexual seria capaz de constituir dano ("detriment") à luz do Sex Discrimination Act. Superando as barreiras filológicas, a Corte sustentou que, não obstante o dicionário definir o assédio como uma "conduta contínua", um incidente singular, desde que suficientemente grave, bastaria para configurar um ato discriminatório contra a mulher. ${ }^{\mathbf{5 6}}$

Outra questão relevante diz respeito à desnecessidade de dolo do empregador para configurar o assédio sexual no trabalho, porquanto a prática pode ser indiferente ou até mesmo contrária aos anseios empresariais, mas não retira a sua responsabilidade caso aquiesça ou deixe de tomar as providências cabíveis para evitar a degradação das condições de trabalho. ${ }^{\mathbf{5 7}}$ A exigência de tal requisito para o assédio em sentido lato, além de representar uma interpolação completamente descabida nos documentos legislativos mais modernos, pode implicar a negação do direito por via oblíqua, em face da extrema dificuldade de se demonstrar a intenção (dolo direto) do agente. Boa parte das normas mencionadas (e.g., Estados Unidos, Portugal, França etc.) é clara ao definir assédio como a conduta que tenha um "objetivo ou efeito" prejudicial, afastando a necessidade da produção de “prova diabólica”, que, em última análise, serve de escudo impessoal e descomprometido para recusar o cumprimento das promessas legislativas de tutela contra o ilícito. Até porque, se determinado ambiente de

55 Sem um paralelo exato no direito do trabalho brasileiro, a figura mais assemelhada à "constructive dismissal" ou "constructive discharge" é a "rescisão indireta", prevista no art. 483 da CLT (BRASIL, 1943). De acordo com a definição do The Law Dictionary, trata-se da situação em que o empregador torna o ambiente de trabalho tão insalubre que o empregado se demite, mantendo o direito à indenização como se tivesse sido dispensado: "What is CONSTRUCTIVE DISMISSAL? A situation where an employer makes working so miserable the employee must quit. The employee keeps their compensation as if they were fired. AKA constructive discharge. Refer to unfair dismissal”.

56 No acórdão, decidiu-se que: '[...] a single act of sexual harassment was a 'detriment' to the complainant within the meaning of s.6(2)(b), not with standing the dictionary definition of 'harassment' as a continuing course of conduct. A single incident of sexual harassment, provided it is sufficiently serious, clearly falls within the proper intention and meaning of the statute as it is an act of discrimination against a woman because she is a woman".

57 Às vezes, nem mesmo a prova da tomada de precauções é suficiente para eliminar a responsabilidade. Na Inglaterra (2006), em Majrowski v. Guy's and St Thomas' NHS Trust [2006] UKHL 34, a Câmara dos Lordes entendeu que a responsabilidade do comitente ("vicarious liability") pelo assédio sexual é objetiva ("strict liability”). Já a Câmara Social da Corte de Cassação francesa entendeu que o empregador possui uma "obrigação de segurança de resultado" em matéria de saúde dos empregados e viola essa obrigação quando os empregados são vítimas de violência física ou psicológica no local de trabalho, ainda que tenha tomado medidas a fim de cessar tais condutas: “L'employeur, tenu d'une obligation de sécurité de résultat en matière de protection de la santé et de la sécurité des travailleurs, manque à cette obligation lorsqu'un salarié est vicitme sur le lieu de travail de violences physiques ou morales, exercées par l'un ou l'autre de ses salariés, quand bien même il aurait pris des mesures en vue de faire cesser ces agissements" (FRANÇA, 2010). 
trabalho afronta a dignidade da pessoa humana, promove a discriminação de gênero ou o preconceito baseado no sexo, o elemento volitivo do causador do dano não tem nenhuma relevância no direito à reparação, conforme explicitado no Employment Equality Act 1998 (IRLANDA, 2012). ${ }^{\mathbf{5 8}}$

Finalmente, um aspecto alarmante que aparece na doutrina brasileira diz respeito à aferição da "culpa concorrente" da vítima, fundada no fato de ela se vestir de forma provocativa, aceitar determinadas intimidades em público ou diante de sua "vida pregressa". ${ }^{99}$ A linha de raciocínio é equivocada, na medida em que não é a indumentária ou o comportamento da vítima que motiva o agressor, pois, mesmo quando as mulheres percebem as agressões e mudam suas atitudes, os ataques não cessam (MENA, 2004), até porque eles respondem muito menos às necessidades sexuais do ofensor do que ao exercício de dominação cultural. Ademais, as vítimas incluem crianças, anciãs, religiosas e mulheres que não atendem aos padrões de beleza socialmente estabelecidos, o que torna a alegação falaz (CRUZ PÉREZ, 2007, p. 104, n. 8). Por outro lado, é moralmente castrador afirmar a possibilidade de culpa da vítima em razão das suas roupas, pois isso significa tolher a liberdade de ela se vestir como melhor lhe aprouver, devendo exibir trajes e aparência física menos atrativos, sob pena de ser culpada por não ter passado incólume aos olhos do agressor. Não bastasse tudo isso, o enigmático conceito de "vida pregressa” a ser supostamente cotejado é um vezo que, no mínimo, torna a vítima refém de seu passado, como se ela pudesse ser escravizada pelo assédio em função de uma conduta pretérita que o julgador - baluarte da moralidade - considera reprovável. Tal circunstância simplesmente não deve ser levada em conta, como determina a legislação da Nova Zelândia (1993), ${ }^{60}$ tida pela doutrina como uma das mais completas sobre a matéria (PAMPLONA FILHO, 2001, p. 86). Em suma, a alegação flerta com a mais preconceituosa "vitimologia”, segundo a qual a pessoa é assediada porque "provoca" ou "deseja”. Isso inibe as denúncias e a prevenção ao assédio, pois, não reconhecida como vítima, ela sofre dupla violência ao ser res-

58 O documento irlandês assim salienta: "The intention of the perpetrator of the sexual harassment or harassment is irrelevant. The fact that the perpetrator has no intention of sexually harassing or harassing the employee is no defence. The effect of the behaviour on the employee is what is relevant".

59 Para Pamplona Filho (2001, p. 50), “[...] se a vítima tem o hábito de se vestir de forma provocadora ou se pactua livremente com certas intimidades em público, não há como deixar de reconhecer que, de certa forma, está assumindo o risco de receber propostas de natureza sexual. [...] o comportamento da alegada vítima, bem como sua 'vida pregressa', deve ser levado em consideração na hora de avaliar se um ato pode O item 62 do Human Rights Act n. 82 (1993) preleciona que: "62. Sexual harassment. (4) Where a person complains of sexual harassment, no account shall be taken of any evidence of the person's sexual experience or reputation”.

60 O item 62 do Human Rights Act n. 82 (1993) preleciona que: "62. Sexual harassment. (4) Where a person complains of sexual harassment, no account shall be taken of any evidence of the person's sexual experience or reputation". 
ponsabilizada pelo comportamento do agressor (DAVID, 2003-2004). Portanto, por mais “provocantes" que sejam os trajes, "atraente" a vítima e "extrovertido" o seu comportamento, uma vez rechaçada a conduta e nela persistindo o agente, caracteriza-se o assédio sexual (LEIRIA, 2012, p. 63).

\section{Conclusão}

A busca pela genuína igualdade de gênero na relação capital e trabalho passa pelo reconhecimento de que a inserção da mulher no mercado perturbou as relações de poder entre os sexos, na medida em que implicou a transgressão de paradigmas culturais que outorgavam somente ao homem o mister de participar das relações sociopolíticas. Como não é natural ao ser humano ceder qualquer parcela de sua soberania de modo afável, a repulsa à companhia feminina no ambiente de trabalho também se manifesta por meio de condutas ilícitas pautadas pela conotação sexual, no afã de criar uma atmosfera de hostilidade e intimidação. Nesse contexto, o assédio sexual surge, em diversas oportunidades, como expressão da violência de gênero, estratagema ardilosamente empregado para que as mulheres capitulem diante dos instrumentos de força.

A investigação do fenômeno revela um extenso rol de sutilezas e contingências a demonstrar que a abordagem de gênero possui um leque de predicados que não permitem ignorá-la - como inadvertidamente fez o Código Penal brasileiro -, ao mesmo tempo que está permeada de riscos e vulnerabilidades que tampouco recomendam sua adoção exclusiva. Dessa forma, propõe-se comedimento e preocupações holísticas para equilibrar-se na linha tênue a divisar proteção e discriminação, a fim de distinguir situações em que o preconceito baseado no sexo realmente está em jogo. Sob tal prisma, a correlação mais adequada entre assédio sexual e discriminação é feita quando o ato é cometido como forma de repetição de estereótipos e normas de gênero, o que pode ocorrer tanto na modalidade "por chantagem" quanto na "por intimidação". Nas demais situações, a violação à liberdade sexual, à dignidade da pessoa humana e ao direito ao meio ambiente saudável e equilibrado são construtos teóricos eficientes e não eliminatórios entre si que também oferecem um conjunto de apetrechos bastante adequados ao equacionamento das questões jurídicas eventualmente postas à tutela jurisdicional. 


\section{REFERÊNCIAS BIBLIOGRÁFICAS}

ANTONMATTEI, Paul-Henri et al. Les risques psychosociaux: identifier, prévenir, traiter. Paris: Lamy, 2010.

ARistÓTEleS. A Política. 3. ed. Tradução Roberto Leal Ferreira. São Paulo: Martins Fontes, 2006.

BARROS, Alice Monteiro de. O assédio sexual no Direito do Trabalho Comparado. Revista LTr, v. 62, n. 11, p. 1464-1476, nov. 1998.

BEAUVOIR, Simone de. O segundo sexo: 1. fatos e mitos. 4. ed. Tradução Sérgio Milliet. São Paulo: Difusão Europeia do Livro, 1970.

BELMONTE, Alexandre Agra. A tutela das liberdades nas relações de trabalho: limites e reparação das ofensas às liberdades de consciência, crença, comunicação, manifestação do pensamento, expressão, locomoção, circulação, informação, sindical e sexual do trabalhador. São Paulo: LTr, 2013.

BÍBLIA. Gênesis. Bíblia Sagrada: nova versão internacional. Tradução Sociedade Bíblica Internacional. São Paulo: Vida, 2000.

BITENCOURT, Cezar Roberto. Princípios fundamentais do Direito Penal. Revista Brasileira de Ciências Criminais, v. 15, p. 81-88, jul. 1996.

BROWNE, Kinglsey R. Title VII as Censorship: Hostile-Environment Harassment and the First Amendment. Ohio State Law Journal, v. 52, 1991.

CLARKE, Linda. Sexual Harassment Law in the United States, the United Kingdom and the European Union: Discriminatory Wrongs and Dignitary Harms. Common LawWorld Review, v. 36, n. 2, p. 79-105, jun. 2007.

CÓDIGO de Hamurabi; Código de Manu, excertos (livros oitavo e nono): Lei das XII Tábuas. 2. ed. Supervisão editorial Jair Lot Vieira. Bauru: Edipro, 2002.

CRUZ PÉREZ, María del Pilar. Hostigamiento sexual, un problema de salud laboral e inequidad de género. Revista GénEros, Universidad de Colima, México, año 13, n. 36, feb. 2007.

DAVID, Natacha. Sexual harassment: prevention versus power relations. Violence at work, International Labour Organization (ILO), Labour Education 2003/2004, n. 133. Disponível em: <http: / /www.ilo.org/ wcmsp5/groups/public/@ed_dialogue/@actrav/documents/publication/wcms_111456.pdf >. Acesso em: 8 maio 2016. 
DRAPEAU, Maurice. Le Harcèlement Sexuel au Travail. Québec: Les Éditions Yvon Blais, 1991.

DWORKIN, Ronald. Soverein virtue: the theory and practice of equality. Cambridge: Harvard University Press, 2000.

ELSESSER, Kim; ANNE, Letitia. The glass partition: obstacles to cross-sex friendships at work. Human Relations, v. 59, p. 1077-1100, Aug. 2006.

FARIA, Carlos Aurélio Pimenta de. Entre marido e mulher, o Estado mete a colher: reconfigurando a divisão do trabalho doméstico na Suécia. RBCS, v. 17, n. 48, p. 173-231, fev. 2002.

FELKER, Reginald Delmar Hintz. O dano moral, o assédio moral e o assédio sexual nas relações de trabalho: doutrina, jurisprudência e legislação. 3. ed. rev. São Paulo: Ltr, 2010.

FRANKE, Katherine M. What's Wrong with Sexual Harassment. In: MACKINNON, Catharine A.; SIEGEL, Reva B. (Eds.). Directions in sexual harassment law. New Haven: Yale University Press, 2004.

GOLDSTEIN, Eduardo. La discriminatión racial por origen nacional y etnia en las relaciones laborales. Montevideo: Fundación Cultura Universitaria, 2009.

GOUGES, Olympe de. Déclaration des Droits de la Femme et de la Citoyenne. Paris, 1793. Disponível em: <http://www.assemblee-nationale.fr/histoire/femmes/olympe-de-gouges_declaration-des-droitsde-la-femme.asp >. Acesso em: 13 jan. 2014.

GUERRA, Raquel Diniz. Mulher e discriminação. Belo Horizonte: Fórum, 2011.

HIRATA, Helena; KERGOAT, Danièle. Divisão sexual do trabalho profissional e doméstico: Brasil, França, Japão. In: COSTA, Albertina de Oliveira; SORJ, Bila; BRUSCINI, Cristina; HIRATA, Helena (Orgs.). Mercado de trabalho e gênero: comparações internacionais. Rio de Janeiro: FGV, 2008.

HIRIGOYEN, Marie-France. Mal-estar no trabalho: redefinindo o assédio moral. 7. ed. Rio de Janeiro: Bertrand Brasil, 2012.

INSTITUTO BRASILEIRO DE GEOGRAFIA E ESTATÍSTICA (IBGE). Síntese de indicadores sociais: uma análise das condições de vida da população brasileira: 2013. Rio de Janeiro: IBGE, 2013.

JAKUTIS, Paulo. Manual de estudo da discriminação no trabalho: estudos sobre discriminação, assédio sexual, assédio moral e ações afirmativas, por meio de comparações entre o Direito do Brasil e dos Estados Unidos. São Paulo: LTr, 2006. 
KANT, Immanuel. Fundamentação da metafísica dos costumes. Tradução Paulo Quintela. Lisboa: Edições 70, 2007.

KAY, Herma Hill; WEST, Martha S. Sex-based Discrimination: text, case and materials. Saint Paul: West Group, 2002.

KYMLICKA, Will. Filosofia política contemporânea: uma introdução. Tradução Luís Carlos Borges e Marilene Pinto Michael. São Paulo: Martins Fontes, 2006.

LEIRIA, Maria de Lourdes. Assédio sexual laboral, agente causador de doenças do trabalho: reflexos na saúde do trabalhador. São Paulo: LTr, 2012.

LIMA, Firmino Alves. Assédio sexual e o meio ambiente do trabalho. Revista da Associação dos Magistrados da Justiça do Trabalho da $15^{a}$ Região - AMATRA XV, Campinas, n. 4, p. 154-172, 2011.

MADALOZZO, Regina; MARTINS, Sergio Ricardo; SHIRATORI, Ludmila. Participação no mercado de trabalho e no trabalho doméstico: homens e mulheres têm condições iguais? Revista Estudos Feministas, Florianópolis, v. 18, n. 2, mai-ago. 2010. Disponível em: <http://dx.doi.org/10.1590/ S0104-026X2010000200015>. Acesso em: 14 jan. 2014.

MALLET, Estêvão. Igualdade e discriminação em Direito do Trabalho. São Paulo: LTr, 2013.

MARZAGÃO JÚNIOR, Laerte Idalino. Assédio sexual e seu tratamento no direito penal. São Paulo: Quartier Latin, 2006.

MELO, Hildete Pereira. O serviço doméstico remunerado no Brasil: de criadas a trabalhadoras. In: Diagnóstico do Setor Serviços no Brasil, Rio de Janeiro: Dipes/Ipea, 1998.

MENA, Carolina Gomez. OMS: sufre acoso sexual 25\% de la población femenina mundial. La Jornada, 12 abr. 2004. Disponível em: <http://www.jornada.unam.mx/2004/04/12/035n1 soc.php?printver= $1 \&$ fly $=1>$. Acesso em: 17 jan. 2014.

MUÇOUÇAH, Renato de Almeida Oliveira. Assédio sexual e a ainda insuficiente discussão acerca das tutelas penal e trabalhista na proteção dos direitos fundamentais da pessoa do trabalhador. Revista LTr, v. 77, n. 6, p. 712-721, jun. 2013.

NASCIMENTO, Sônia Mascaro. Assédio moral e dano moral no trabalho. 3. ed. São Paulo: LTr, 2015.

PAMPLONA FILHO, Rodolfo. O assédio sexual na relação de emprego. São Paulo: LTr, 2001. 
PSIQWEB. Critérios Diagnósticos para F60.4 - 301.50 Transtorno da Personalidade Histriônica. Disponível em: <http://www.psiqweb.med.br/>. Acesso em: 18 jan. 2014.

PUCCI, Claudio. Perfil social, racial e de gênero das 500 maiores empresas do Brasil e suas ações afirmativas: pesquisa 2010. São Paulo: Ethos, 2010.

QUINN, Beth A. The Paradox of Complaining: Law, Humor, and Harassment in the Everyday Work World. Law \& Social Inquiry, v. 25, p. 1151-1181, Oct. 2000.

ROSHCHIN, A. V. Protection of the Working Environment. International Labour Review, v. 110, p. 235 249, 1974.

SCHREIBER, Anderson. Novos paradigmas da responsabilidade civil: da erosão dos filtros da reparação à diluição dos danos. São Paulo: Atlas, 2007.

SCHULTZ, Vicki. Reconceptualizing Sexual Harassment. Yale Law Journal, v. 107, n. 6, p. 1683$1805,1998$.

SHAVELL, Steven. Foundation of Economic Analisys of Law. Cambridge: Harvard University Press, 2004.

SILVA, Itatiara Meurilly Santos. Princípio da igualdade e o trabalho da mulher. Âmbito Jurídico, n. 68, set. 2009. Disponível em: <http://www.ambito-juridico.com.br/site/index.php?n_link=revista_ artigos_leitura\&artigo_id=673\%201>.Acesso em: 10 jan. 2014.

SOUZA DIAS, Eleonora de Paula; CASARA, Marques; WERLE, Sandra. Condenada por ser mulher. Observatório Social em Revista, ano 2, n. 5, mar. 2004.

STERN, Seth; WERMIEL, Stephen. Justice Brennan: Liberal Champion. New York: Hougnton Mifflin Harcourt, 2010.

TEIXEIRA, Daniel Viana. Desigualdade de gênero: sobre garantias e responsabilidades sociais de homens e mulheres. Revista Direito GV, São Paulo, v. 11, p. 253-274, jan.-jun. 2010.

THE LAW DICTIONARY. Featuring Black's Law Dictionary Free Online Legal Dictionary. 2. ed. Disponível em: <http://thelawdictionary.org/constructive-dismissal>. Acesso em: 6 jan. 2014.

THOME, Candy Florencio. O princípio da igualdade de gênero e a participação das mulheres nas organizações sindicais de trabalhadores. São Paulo: LTr, 2012. 
TOMEI, Manuela; VEGA-RUIZ, María Luz. La discriminación de la mujer en el lugar de trabajo: nuevas tendencias en materia de discriminación por motivos basados en la maternidad y el acoso sexual. Revista Latinoamericana de Derecho Social, n. 4, p. 149-174, enero-jun. 2007.

WALLERSTEIN, Immanuel. Capitalismo histórico e civilização capitalista. Tradução Renato Aguiar. Rio de Janeiro: Contraponto, 2001.

\section{Legislação e jurisprudência}

ARGENTINA. Decreto Nacional n. 2.385/93. Acoso Sexual en la Administración Pública Nacional, de 18 de noviembre de 1993. Disponível em: <http://www.cnm.gov.ar/LegNacional/DECRETO_ 2385. pdf>. Acesso em: 15 jan. 2014.

BÉLGICA. Arrêté royal relatif à la prévention de la charge psychosociale occasionnée par le travail dont la violence, le harcèlement moral ou sexuel au travail. 17 mai. 2007. Disponível em: <http://www. emploi.belgique.be/defaultTab.aspx?id=564>. Acesso em: 9 jan. 2014.

. Directive 2002/73/CE du Parlement européen et du Conseil du 23 septembre 2002. Journal officiel n. L 269 du 5/10/2002, p. 0015-0020. Disponível em: <http:// eur-lex.europa.eu/ legal-

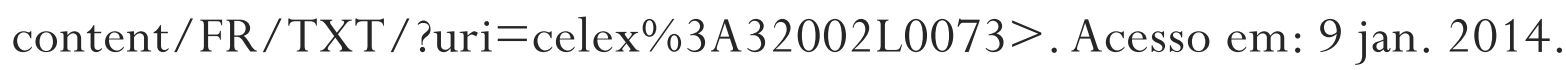

. Loi relative à la protection contre la violence et le harcèlement moral ou sexuel au travail. (L. 11-06-2002). Disponível em: <http://www.gallilex.cfwb.be/document/pdf/27466_000.pdf>. Acesso em: 11 jan. 2014.

BRASIL. Código Penal. Decreto-lei n. 2848, de 7 de dezembro de 1940. Disponível em: <http:// www.planalto.gov.br/ccivil_03/decreto-lei/Del2848.htm>. Acesso em: 9 mai. 2016.

. Consolidação das Leis do Trabalho. Decreto-lei n. 5452, de $1^{\circ}$ de maio de 1943. Disponível em:

<http://www.planalto.gov.br/ccivil_03/decreto-lei/Del5452.htm>. Acesso em: 9 mai. 2016.

. Constituição (1988). Constituição da República Federativa do Brasil. Brasília, DF: Senado, 1988.

Disponível em: <http://www.planalto.gov.br/ccivil_03/Constituicao/Constituicao.htm>. Acesso em: 9 mai. 2016.

. Constituição (1988). Emenda Constitucional n. 72, de 2 de abril de 2013a. Disponível em: <http:/ / www.planalto.gov.br/ccivil_03/Constituicao/Emendas/Emc/emc72.htm>. Acesso em: 9 mai. 2016. 
BRASIL. Lei n. 12.873, de 24 de outubro de 2013b. Disponível em: <http:/ /www.planalto.gov.br/ ccivil_03/_ato2011-2014/2013/Lei/L12873.htm>. Acesso em: 9 mai. 2016.

. Lei n. 6.938, de 31 de agosto de 1981. Disponível em: <http://www.planalto.gov.br/ ccivil_03/leis/L6938.htm>. Acesso em: 9 mai. 2016.

. Lei n. 7.855, de 24 de outubro de 1989. Disponível em: <http://www.planalto.gov.br/ ccivil_03/leis/L7855.htm>.Acesso em: 9 mai. 2016.

Lei n. 9.029, de 13 de abril de 1995. Disponível em: <http://www.planalto.gov.br/ ccivil_03/LEIS/L9029.HTM>. Acesso em: 9 mai. 2016.

.Tribunal Superior do Trabalho. Enunciados Aprovados. $1^{\mathrm{a}}$ Jornada de Direito Material e Processual na Justiça do Trabalho, Brasília, 23 nov. 2007. Disponível em: <http://www.nucleotrabalhistacalvet. com.br/ novidades/1jornadadedireiro.pdf>. Acesso em: 17 jan. 2014.

Tribunal Superior do Trabalho. $1^{\mathrm{a}}$ Turma. $R R-13490-70.2007 .5 .14 .0002$. Relator: José Maria Quadros de Alencar. Julgado em 17 de dezembro de 2013c.

CANADÁ. Code canadien du travail (L.R.C. (1985), ch. L-2). Disponível em: <http://lawslois.justice.gc.ca/fra/lois/l-2/index.html?pedisable=true $>$. Acesso em: 16 jan. 2014.

. Supreme Court of Canada. Janzen v. Platy Enterprises Ltd., [1989] 1 S.C.R. 1252. Disponível em: <https://archive.org/stream/boi116/boi116_djvu.txt>.Acesso em: 8 jan. 2014.

CHILE. Código del Trabajo, de 31 de julho de 2002. Disponível em: <http://www.dt.gob.cl/ legislacion/1611/articles-95516_recurso_1.pdf>. Acesso em: 9 jan. 2014.

COSTA RICA. Ley n. 7476, de 3 de febrero de 1995, contra el hostigamiento sexual en el empleo y la docencia. Disponível em: <http://www.ilo.org/dyn/natlex/docs/WEBTEXT/40119/64952/ S95CRI01.htm>. Acesso em: 6 jan. 2014.

ESPANHA. Codigo Penal de España (1995). Ley Orgánica 10/1995, de 23 de noviembre. Disponível em: <https://www.boe.es/buscar/pdf/1995/BOE-A-1995-25444-consolidado.pdf>. Acesso em: 15 jan. 2014.

ESTADOS UNIDOS DA AMÉRICA (EUA). Code of Federal Regulations. Title 29. Labor. Part 1604. Guidelines on Discrimination Because of Sex. Disponível em: <http://www.gpo.gov/fdsys/pkg/ CFR-2009-title29-vol4/pdf/CFR-2009-title29-vol4-sec1604-11.pdf>. Acesso em: 15 jan. 2014. 
ESTADOS UNIDOS DA AMÉRICA (EUA). Supreme Court of the United States. Bradwell v. The State, 83 U.S. 130 (1872). Julgado em 15 de abril de 1873. Disponível em: <http://supreme.justia.com/ cases/federal/us/83/130/ case.html>. Acesso em: 11 jan. 2014.

Supreme Court of the United States. Goesaert v. Cleary, 335 U.S. 464 (1948). Julgado em 20 de dezembro de 1948. Disponível em: <https://supreme.justia.com/cases/federal/us/335/464/ case.html>. Acesso em: 11 jan. 2014.

Supreme Court of the United States. Harris v. Forklift Systems, Inc. - 510 U.S. 17 (1993). Disponível em: <http://supreme.justia.com/cases /federal/us/510/17/case.html>. Acesso em: 8 jan. 2014.

Supreme Court of the United States. Meritor Savings Bank v.Vinson - 477 U.S. 57 (1986). Disponível em: <http://supreme.justia.com/cases/ federal/us/477/57/case.html>. Acesso em: 15 jan. 2014.

Supreme Court of the United States. Oncale v. Sundowner Offshore Services, 523 U.S. 75 (1998). Disponível em: <http://supreme.justia.com/cases/federal/us/523/75/case.html>. Acesso em: 15 jan. 2014.

. United States Court of Appeals, Eighth Circuit. Jenson v. Eveleth Taconite Company. 97-1147. December 05, 1997. Disponível em: <http: / / caselaw.findlaw.com/us-8th-circuit/1136685. html >. Acesso em: 10 jan. 2014.

FRANÇA. Code du Travail. Loi n 2008-67 du 21 janvier 2008. Disponível em: <http: / www.legifrance. gouv.fr>.Acesso em: 15 jan. 2014.

. Code penal. Loi n 92-684 du 22 juillet 1992. Disponível em : <www.legifrance.gouv.fr>. Acesso em: 15 jan. 2014.

. Cour de cassation. Chambre sociale. Audience publique du mercredi 3 février 2010. $\mathrm{N}^{\circ}$ de pourvoi: 08-40144. Disponível em: <www.legifrance.gouv.fr>. Acesso em: 27 jan. 2014.

INDIA. Sexual Harassment of Women at Workplace (Prevention, Prohibition and Redressal) Act, 2013. Disponível em: <http://indiacode.nic.in/acts-in-pdf/142013.pdf>. Acesso em: 27 jan. 2014.

. Supreme Court of India. Vishaka and others v. State of Rajasthan and others. (AIR 1997 SC 3011). Disponível em: <http://www.iiap.res.in/ files/VisakaVsRajasthan_1997.pdf>. Acesso em: 4 jan. 2014. 
INDIA. The Constitution of India, de 1949. Disponível em: <http:/ /awmin.nic.in/ olwing/coi/ coi-english/Const.Pock\%202Pg.Rom8Fsss(6).pdf>. Acesso em: 8 jan. 2014.

INGLATERRA. Employment Appeal Tribunal. Bracebridge Engineering Ltd v. Darby [1990] IRLR 3 EAT. Disponível em: <http:/ / people.exeter.ac.uk/rburnley/empdis/1990IRLR3.html>. Acesso em: 6 jan. 2014.

. House of Lords. Majrowski (Respondent) v. Guy's and StThomas' NHSTrust (Appellants) [2006] UKHL 34. Julgado em 12 de julho de 2006. Disponível em: <http://www.publications. parliament.uk/pa/ld200506/ldjudgmt/jd060712/majro.pdf>. Acesso em: 27 jan. 2014.

Sex Discrimination Act, 1975. Equal Opportunities Comission, 24 june 2004. Disponível em: <http://www.wcwonline.org/pdf/lawcompilation/England-sex\%20discrimination.pdf>. Acesso em: 13 jan. 2014.

IRLANDA. Employment Equality Act 1998 (Code of Practice) (Harassment) Order 2012. Disponível em: <http://www.irishstatutebook.ie/pdf/2012/en.si.2012.0208.pdf>. Acesso em: 17 jan. 2014.

ITÁLIA. Corte Suprema di Cassazione. Cass., sez. lav., 18 aprile 2000 n. 5049. Disponível em: <http://www.cortedicassazione.it >. Acesso em: 14 jan. 2014.

Corte Suprema di Cassazione. Cass., sez. lav., 19 maggio 2010 n. 12318. Disponível em: <http://digilander.libero.it/dirittodellavoro>. Acesso em: 10 jan. 2014.

. Codice civile (Regio Decreto 16 marzo 1942, n. 262). Disponível em: <http:/ / www.altalex. com/index.php?idnot=34794>. Acesso em: 18 jan. 2014.

. Codice Dell'Ambiente (Testo coordinato del Decreto legislativo n. 152 del 3 aprile 2006). Disponível em: <http://www.altalex.com/index.php?idnot=33891>. Acesso em: 17 jan. 2014.

. Decreto Legislativo 30 maggio 2005, n. 145. Disponível em: <http://www.parlamento. it/parlam/leggi/deleghe/05145dl.htm>. Acesso em: 27 jan. 2014.

MINNESOTA. 2013 Minnesota Statutes. 549.20. Punitive Damages. Disponível em: <https: / /www. revisor.leg.state.mn.us/statutes/?id=549.20>. Acesso em: 18 jan. 2014.

NOVA ZELÂNDIA. Human Rights Act n. 82 (1993). Disponível em: <http: / / www.legislation.govt.nz/ act/public/1993/0082/latest/versions.aspx>. Acesso em: 10 jan. 2014. 
ORGANIZAÇÃO DAS NAÇÕES UNIDAS (ONU). Conferência das Nações Unidas sobre Meio Ambiente e Desenvolvimento. Declaração do Rio sobre Meio Ambiente e Desenvolvimento. Rio de Janeiro, 1992. Disponível em: <http://www.onu.org.br/rio20/img/2012/01/rio92.pdf>. Acesso em: 18 jan. 2014.

ORGANIZAÇÃO DOS ESTADOS AMERICANOS (OEA). Convención Interamericana para Prevenir, Sancionar y Erradicar la Violencia contra la Mujer. Belém, 1994. Disponível em: <http: / /www.oas.org/ juridico/spanish/tratados/a-61.html>. Acesso em: 16 jan. 2014.

PARAGUAI. Código Penal de la República del Paraguay. Ley no ${ }^{\circ}$ 1.160/97. Disponível em: <http://www.mre.gov.py/v1/Adjuntos/Privacidad/Ley1160.pdf>.Acesso em: 15 jan. 2014.

PORTUGAL. Código do Trabalho (2009). Disponível em: < dre.pt/pdf1s/2009/02/03000/0092601029. pdf $>$. Acesso em: 31 jan. 2014.

RIO DE JANEIRO (Estado). Tribunal Regional do Trabalho da $1^{\text {a }}$ Região. $7^{\mathrm{a}}$ Turma. RO 03325-2002244-01-00-0. Relator: Evandro Pereira Valadão Lopes. Diário da Justiça do Rio de Janeiro, 30 ago. 2004.

. Tribunal Regional do Trabalho da $1^{a}$ Região. 6 ${ }^{a}$ Turma. RO 0142600-21.2008.5.01.0322. Julgado em 5 de outubro de 2011. Relator: Marcelo Antero de Carvalho.

SUÉCIA. Parental Leave Act (1995:584). Issued 24 May 1995. Disponível em: <http:/ /www.government. se/content/1/c6/10/49/85/f16b785a.pdf>. Acesso em: 14 jan. 2014.

Flávio da Costa Higa Pós-Doutorando em CIÊNCIAS JuRídICO-EMPRESARIAIS PELA UNIVERSIDADE DE LISBOA. Doutor e Mestre em Direito do Trabalho pela Universidade de São Paulo (USP).

Professor da Escola da Magistratura Trabalhista do Mato Grosso do Sul (Ematra-MS).

Juiz do Trabalho em Coxim (MS).

fhigaatrt24.jus.br 